\title{
In situ reverse transcriptase-nested polymerase chain reaction to identify intracellular nucleic acids without the necessity of DNAse pretreatment and hybridisation
}

\author{
Mario Menschikowski * , Margot Vogel, \\ Rolf Eckey, Gerd Dinnebier and \\ Werner Jaross \\ Institut für Klinische Chemie und \\ Laboratoriumsmedizin, Technische Universität \\ Dresden, Medizinische Fakultät "Carl Gustav \\ Carus”, Fetscherstrasse 74, D-01307 Dresden, \\ Germany
}

Received 17 November 2000

Accepted 20 February 2001

In the present study a protocol of in situ reverse transcriptasenested polymerase chain reaction (in situ RT-nested PCR) was examined based on the following modifications. (i) To exclude false positive signals caused by "DNA repair mechanisms" and "endogenous priming", a two-step PCR was applied after reverse transcription. The first step was performed in the presence of extrinsic primers and unlabeled nucleotides with a maximum of PCR cycles possible without destroying the cell morphology. The second step consisted of only one annealing/elongation reaction, the target sequence marked by addition of digoxigenin-labeled nucleotides and intrinsic primers. (ii) In order to prevent amplifications of genomic DNA nested primer pairs were applied crossing intron sequences. (iii) To minimize the diffusion of PCR products in cells, the extrinsic primers were extended with complementary $5^{\prime}$-tails. This approach results in the generation of high molecular weight concatamers dur-

\footnotetext{
${ }^{*}$ Corresponding author: Dr. Mario Menschikowski, Institut für Klinische Chemie und Laboratoriumsmedizin, Technische Universität Dresden, Medizinische Fakultät "Carl Gustav Carus", Fetscherstrasse 74, D-01307 Dresden, Germany. Tel.: +49 351458 2634; Fax: +49 351458 4332; E-mail: menschik@ rcs1.urz.tudresden.de.
}

ing PCR cycles. By applying this protocol, immunostainings specific for phospholipase $A_{2}$ of type IIA mRNA were exclusively detectable in the cytoplasm of HepG2 hepatoma cells, which were used as a model system, whereas the nuclei were unstained. Multiple control experiments yielded completely negative results. These data suggest that the in situ RT-nested PCR, which in comparison to the method of in situ RT-PCRin situ-hybridisation is simpler and less time-consuming, can be used as an alternative approach to identify intracellular nucleic acids.

\section{Introduction}

In comparison to in situ hybridisation (ISH), the in situ RT-PCR technique provides a higher level of sensitivity, theoretically allowing the identification of a single gene copy per single cell. Despite this, the technique would find application neither in research nor in diagnosis to the extent expected. One explanation of this is that if detection of DNA or RNA is based on the incorporation of labeled nucleotide into amplified products, serious artifacts are possible, generated by (i) the incorporation of nucleotides into fragmented endogenous DNA mediated by the exonuclease activity of DNA polymerases ("DNA repair mechanisms"), (ii) the priming of nonspecific PCR products with cDNA or DNA fragments ("endogenous priming of DNA-fragments"), or (iii) the diffusion of PCR products from the site of synthesis to other sites of the cells, even to neighboring cells ("diffusion artifacts") [9-11,19]. Because even a prior DNAse treatment of the cells or tissues [7], the use of exonucleasefree DNA polymerase [9], "repairing" of DNA nicks with T4 ligase [8], or an initial thermal cycling using unlabeled nucleotides [16] were insufficient to 
exclude these artifacts completely, a further in situhybridisation step with labeled nucleic acid probe (in situ-RT-PCR-ISH) is indispensable. However, higher technological and time requirements in connection with this technique will largely hinder its broad application, especially in routine laboratory work.

The objective of this study was to optimize the method of in situ-RT-PCR with the purpose of making a specific identification of mRNA molecules possible without hybridisation and prior DNAse treatment, despite the difficulties occurring in the in situ amplification of nucleic acids. The modifications in method based on considerations which have previously been described in an abstract form [14]. In a study published by Peters et al. [18] similar modifications were investigated for their effectiveness in excluding false positive results. However, while Peters et al. [18] applied a DNAse pretreatment in the investigation of IL-6 mRNA in paraffin sections of lymph nodes, in the present study it was to be tested, whether the pretreatment with DNAse can be omitted. Ivarsson and Weijdegard [7] have shown that in samples with small amounts of RNA, the RNA was affected by overnight treatment with DNAse.

As a model system we used human HepG2 hepatoma cell cultures, which synthesize and secrete a phospholipase $\mathrm{A}_{2}$ of type IIA $\left(\mathrm{sPLA}_{2}\right)$ into the medium on exposure to proinflammatory cytokines such as interleukin-1 $\beta$ (IL-1 $\beta$ ), interleukin-6 (IL-6) and tumor necrosis factor- $\alpha$ (TNF- $\alpha)$ [4]. Several lines of evidence suggest that this enzyme plays a crucial role in the acute phase reaction of inflammatory disorders. Recently this enzyme could also be identified in human atherosclerotic plaques $[13,15]$. To identify the cellular source of this enzyme in the arterial wall, we were interested in a method with which a low copy number of sPLA $\mathrm{P}_{2}$-specific mRNA can be visualized.

\section{Materials and methods}

\subsection{Cell culture}

Human HepG2 hepatoma cells $\left(2 \times 10^{5}\right.$ cells/ ml $)$ were grown on silanized in situ PCR glass slides (Perkin-Elmer, USA) in Dulbecco's modified Eagle's minimum essential medium containing nonessential amino acids $(1 \%)$, glutamin $(2 \mathrm{mM})$, streptomycin $(100 \mu \mathrm{g} / \mathrm{ml})$, gentamycin $(10 \mu \mathrm{g} / \mathrm{ml})$, and $10 \% \mathrm{fe}-$ tal calf serum. After reaching near confluence, the medium was removed and replaced with fresh medium containing $25 \mathrm{ng} / \mathrm{ml}$ of IL-6 and TNF- $\alpha$. Three days later, the cells were washed with PBS, $\mathrm{pH} 7.2$, and fixed overnight in $4 \%$ buffered paraformaldehyde.

\subsection{Isolation of total RNA from HepG2 cells}

Fixed human HepG2 cells were scraped from glass slides in an area of $1 \mathrm{~cm}^{2}$ and transfered into sterile Eppendorf-tubes. Total RNA was isolated by the acid guanidinium thiocyanate-phenol-chloroform method as described by Chomczynski and Sacchi [2]. The concentration of RNA was determined spectrophotometrically at $260 \mathrm{~nm}$.

\subsection{Identification of $S P L A_{2}$-specific $m R N A$ by solution-phase RT-nested PCR and Southern blot}

Isolated RNA $(0.20 \mu \mathrm{g})$ was converted to cDNA in the presence of $2.5 \mu \mathrm{M}$ reverse transcriptase primers (Table 1) and dNTPs ( $1 \mathrm{mM}$ each) at $42^{\circ} \mathrm{C}$ for $45 \mathrm{~min}$ and at $99^{\circ} \mathrm{C}$ for $5 \mathrm{~min}$ using the GeneAmp RNA PCR Kit (Perkin-Elmer). Subsequently, the cDNA was amplified according to the manufacturer's instructions in the presence of extrinsic primers $(0.4 \mu \mathrm{M}$ each $)$ and Taq DNA polymerase (2.5 U/100 $\mu$ l, Beckman Molecular Biologicals, USA). The sequences of primers used were based on that published for placental sPLA 2 [3] and were designed overspanning intron sequences to prevent the hybridisation with genomic DNA. To minimize the diffusion of products in cells in situ, primers were extended with complementary $5^{\prime}$-tails (Table 1 ), as described by Chiu et al. [1]. To determine the effect of complementary primer tails, the conditions for the PCR were as follows: an initial denaturating step at $94^{\circ} \mathrm{C}$ for $5 \mathrm{~min}$ and 10 cycles at $94^{\circ} \mathrm{C}$ for $1 \mathrm{~min}$ and $70^{\circ} \mathrm{C}$ for $1.30 \mathrm{~min}$ followed by a variable number of further PCR cycles (from 10 to 50 cycles) at $94^{\circ} \mathrm{C}$ for $1 \mathrm{~min}, 52^{\circ} \mathrm{C}$ for $1.30 \mathrm{~min}$, and $70^{\circ} \mathrm{C}$ for $1 \mathrm{~min}$; and finally, an extension step at $70^{\circ} \mathrm{C}$ for $10 \mathrm{~min}$ and cooling to $4^{\circ} \mathrm{C}$. Preliminary investigation showed that the morphology of HepG 2 cells fixed overnight in $4 \%$ buffered paraformaldehyde was preserved after this thermocycling procedure. The buffers and reagents used were the same as those supplied with the GeneAmp RNA PCR Kits (Perkin-Elmer). To establish the extent to which raising the annealing temperature from $52^{\circ} \mathrm{C}$ to $70^{\circ} \mathrm{C}$ during PCR prevents the annealing of the complementary $5^{\prime}$-tails, the following amplification conditions were applied: an initial denaturating step at $94^{\circ} \mathrm{C}$ for $5 \mathrm{~min}$; 60 cycles at $94^{\circ} \mathrm{C}$ for $1 \mathrm{~min}$ and $70^{\circ} \mathrm{C}$ for $2 \mathrm{~min}$; and finally, an extension step at $70^{\circ} \mathrm{C}$ for $10 \mathrm{~min}$ and cooling to $4^{\circ} \mathrm{C}$. The products of amplification were analyzed on ethidium bromide-stained $2 \%$ agarose gels under UV light. 
Table 1

Oligonucleotides used in the present study as primers

\begin{tabular}{llr}
\hline Primer & Sequences & Product \\
\hline reverse & $5^{\prime}$-TTTTTTTTTTGAATTC-3' & \\
transcription & & 447 bp \\
& forward: & \\
& $5^{\prime}$-CCCCAAACCCCAAACCCCGTGATCATGATCTTTGGGCTACT-3' & \\
& reverse: & 245 bp \\
intrinsic & $5^{\prime}$-GGGGTTTGGGGTTTGGGGTCAGCAACGAGGGGTGCTCC-3' & \\
& forward: & \\
& $5^{\prime}$-ATGCAACGGATCGCTGCTGTGTCAC-3' & \\
& reverse: & $5^{\prime}$-CCCTCTGCAGTGTTTATTGGAATA-3' \\
& &
\end{tabular}

For labeling of amplicons, $10 \mu \mathrm{l}$ from the first PCR solution was added to $40 \mu \mathrm{l}$ of PCR reagent solution containing Taq DNA polymerase $(2.5 \mathrm{U} / 100 \mu \mathrm{l})$, digoxigenin (DIG)-labeled nucleotides $(200 \mu \mathrm{M}$, PCR DIG labeling mix, Roche Diagnostics GmbH, Mannheim, Germany), and intrinsic primers ( $0.4 \mu \mathrm{M}$ each) to the samples amplified at an annealing temperature of $52^{\circ} \mathrm{C}$ or extrinsic primers $(0.4 \mu \mathrm{M}$ each $)$ to the samples amplified at $70^{\circ} \mathrm{C}$ in the first PCR step. The second PCR, consisting of one denaturating step at $94^{\circ} \mathrm{C}$ for $1 \mathrm{~min}$ and one annealing/extension step at $70^{\circ} \mathrm{C}$ for $10 \mathrm{~min}$, was performed with the hot start technique by addition of DNA polymerase after preincubation of PCR reagent solution at $70^{\circ} \mathrm{C}$. To analyze whether high molecular weight concatamers contained the specific $\mathrm{sPLA}_{2}$-target sequences, a portion of the products obtained after the second PCR was digested at $37^{\circ} \mathrm{C}$ for $24 \mathrm{~h}$ with $15 \mathrm{U}$ of the restriction endonuclease BsiHKA I (New England BioLabs, USA) in 100 $\mathrm{mM} \mathrm{NaCl}, 50 \mathrm{mM}$ Tris-HCl, pH 7.9, $10 \mathrm{mM} \mathrm{MgCl}_{2}$, $1 \mathrm{mM}$ dithiothreitol and $100 \mu \mathrm{g} / \mathrm{ml} \mathrm{BSA}$.

As negative controls the following approaches were investigated: (a) omission of templates, (b) omission of reverse transcription, (c) preincubation of targets with $2 \mathrm{U}$ of RNAse ONE ${ }^{\mathrm{TM}}$ (Promega, USA) in $20 \mathrm{mM}$ Tris- $\mathrm{HCl}$, pH 7.5, $50 \mathrm{mM}$ EDTA, $2 \mathrm{M}$ sodium acetate at $37^{\circ} \mathrm{C}$ for $10 \mathrm{~min}$ and at $90^{\circ} \mathrm{C}$ for $5 \mathrm{~min}$, (d) omission of extrinsic primer, but not of DNA polymerase in the first PCR, and (e) omission of primer and Taq DNA polymerase in the first PCR.

After finishing the second PCR, separation of amplified DNA by agarose gel electrophoresis, and capillar flow transfer to a nitrocellulose membrane [12], the incorporated DIG labels were detected by using antiDIG antibodies conjugated with alkaline phosphatase (diluted 1:2000; Roche Diagnostics GmbH) and col- orimetric detection with the substrate nitroblue tetrazolium salt and 5-bromo-4-chloro-3-indolyl phosphate according to the manufacturer's instructions.

\subsection{In situ RT-nested PCR}

After fixation and washing $(3 \times$ for $2 \mathrm{~min})$ with PBS, $\mathrm{pH} 7.2$, the cells were incubated with proteinase $\mathrm{K}(1 \mu \mathrm{g} / \mathrm{ml})$ in $50 \mathrm{mM}$ Tris- $\mathrm{HCl}$ buffer, $\mathrm{pH} 8.0$, at $24^{\circ} \mathrm{C}$ for $10 \mathrm{~min}$, and then at $95^{\circ} \mathrm{C}$ for $5 \mathrm{~min}$ to inactivate the enzyme activity. Preinvestigations on HepG2 cell cultures, in which proteinase $\mathrm{K}$ concentrations between $0.1-10.0 \mu \mathrm{g} / \mathrm{ml}$ were used, had shown that with an enzyme concentration of $1 \mu \mathrm{g} / \mathrm{ml}$ the best results could be obtained. Then the cells were dehydrated in graded alcohols and air-dried. Conversion of mRNA into cDNA and amplification of nucleic acids was performed in cells by using the GeneAmp In Situ PCR Systems 1000 thermal cycler (Perkin-Elmer). The reagents and the reaction conditions were the same as described above for the solution-phase RT-nested PCR with the following exceptions: (i) the concentration of $\mathrm{MgCl}_{2}$ was $4 \mu \mathrm{M}$ in reagent solutions of both PCR steps [17], (ii) the master mixture for the first PCR contained additionally dNTPs (400 $\mu \mathrm{M}$ each), (iii) 10 cycles at an annealing temperature of $70^{\circ} \mathrm{C}$ and up to 50 further cycles at an annealing temperature of $52^{\circ} \mathrm{C}$ were performed in the first PCR, (iv) the concentration of intrinsic primers in the second PCR was elevated and averaged $1 \mu \mathrm{M}$. To exclude mispriming and primer oligomerization, the hot start technique was applied in the second PCR by using the assembly tool (PerkinElmer).

Both after reverse transcription and the first PCR, glass slides were treated twice for 1 min with xylol and twice for 1 min with ethanol and then air-dried. 
In this way it was easier to close the reaction chamber without the generation of air-bubbles under the AmpliCover Discs (Perkin-Elmer). A further advantage was that residual extrinsic primers from the first PCR were washed out of the cells, which was important to the application of the nested primers in the second PCR. After finishing the second PCR and after blocking the slides, DIG-labeled nucleotides were detected by applying colloid gold-labeled anti-DIG antibodies ( $1: 20$ diluted) and the silver-enhancement technique according to the manufacturer's instructions (Roche Diagnostics $\mathrm{GmbH}$ ) under light microscopic control.

In approaching the specificity of the method, control experiments with (a) omission of reverse transcription, (b) omission of extrinsic primers, but not of DNA polymerase in the first PCR, (c) omission of primers and Taq DNA polymerase in the first PCR, (d) preincubation of cells with $2 \mathrm{U}$ of RNAse ONE ${ }^{\mathrm{TM}}$ in $20 \mathrm{mM}$ Tris- $\mathrm{HCl}$, pH 7.5, $50 \mathrm{mM}$ EDTA, $2 \mathrm{M}$ sodium acetate at $37^{\circ} \mathrm{C}$ for $10 \mathrm{~min}$ and at $90^{\circ} \mathrm{C}$ for $5 \mathrm{~min}$, and (e) omission of primary antibody in the immunochemical detection of digoxigenin, were performed.

\section{Results}

Figure 1 depicts the generation of high molecular weight concatamers by applying primers with a complementary 5'-tail. After 30 PCR cycles, monomer products with a length of $447 \mathrm{bp}$ were produced (Fig. 1, lane 3). The raising of the number of cycles was accompanied by an amplified polymerization of the monomeric amplicons. After 60 cycles highmolecular-weight products with a length of several thousand base-pairs were observed (Fig. 1, lane 7).

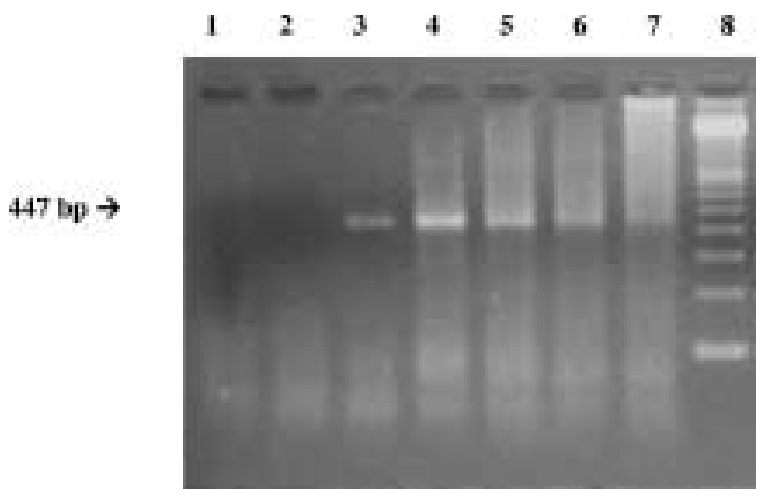

Fig. 1. PCR products generated by solution-phase RT-PCR after 10 (lane 1), 20 (lane 2), 30 (lane 3), 40 (lane 4), 47 (lane 5), 52 (lane 6) and 60 cycles (lane 7 ) in the agarose gel electrophoresis. Lane $8 ; 100$ bp ladders.
In Fig. 2, products arising out of RT-nested PCR are shown in agarose gel electrophoresis (A) and in Southern blot (B). If, instead of $52^{\circ} \mathrm{C}$, an annealing temperature of $70^{\circ} \mathrm{C}$ was selected, the annealing of the complementary $5^{\prime}$-tails could be prevented, and only monomeric products of $447 \mathrm{bp}$ were produced (Fig. 2A, lane 3). In the Southern blot, after as few as one cycle in the second PCR, the monomeric as well as the polymeric amplicons could be immunochemically detected (Fig. 2B, lanes 3 and 10). The incubation of DIG-labeled concatamers with restriction endonuclease $B s i$-HKA I, by which the extrinsic $3^{\prime}$-primer sequence 32 nucleotides away from the $5^{\prime}$-tails were selectively cut, led to 429 bp products (Fig. 2A and B, lanes 9, resp.). Furthermore, in the Southern blot a minor band of 267 bp was recognizable (Fig. 2B, lane 9).

To check the specificity of the method, a series of negative controls was investigated. While in the agarose electrophoresis nonspecific reaction products generated during the first PCR step were recognizable, in the Southern blot all controls were immunochemically negative (Fig. 2B, lanes 4-8).

After evaluation of the RT-nested PCR protocol in tubes, the method was applied in situ to adherent HepG2 cells. The immunostainings observed were exclusively in the cytoplasm of the cells, while the nuclei remained unstained (Fig. 3A). As a comparison, cells are shown in Fig. 3B that were stained with hematoxylin. After pretreatment of the cells with RNAse no immunochemical reactions were observed (Fig. 3C). Also the other controls, which were previously investigated in the Southern blot (Fig. 2B, lanes 4-7), as well as the control in which the first antibody in the immunochemical detection was omitted, yielded negative results (not shown).

\section{Discussion}

In the present study a modified method of in situ RT-nested PCR technique was investigated with respect to its effectiveness in excluding false positive results caused by "DNA repair mechanisms", "endogenous priming", and/or "diffusion artifacts". The methodical modifications arose out of the following considerations: (i) In order to minimize mispriming with other targets, which under certain circumstances exhibit sequence homologies with the target under investigation, instead of oligo $\mathrm{d}(\mathrm{T})_{16}$ in the reverse transcription a reverse oligonucleotide was applied, which along with an oligo $\mathrm{d}(\mathrm{T})_{10}$-segment contains a nu- 
A

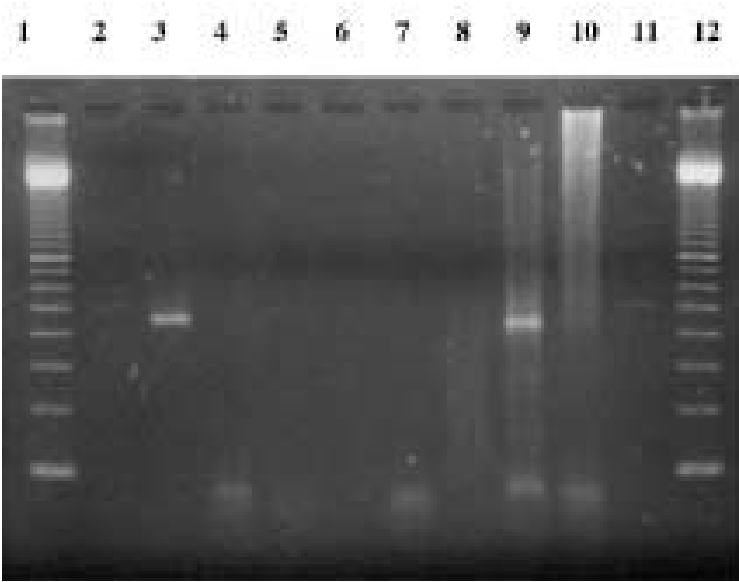

B

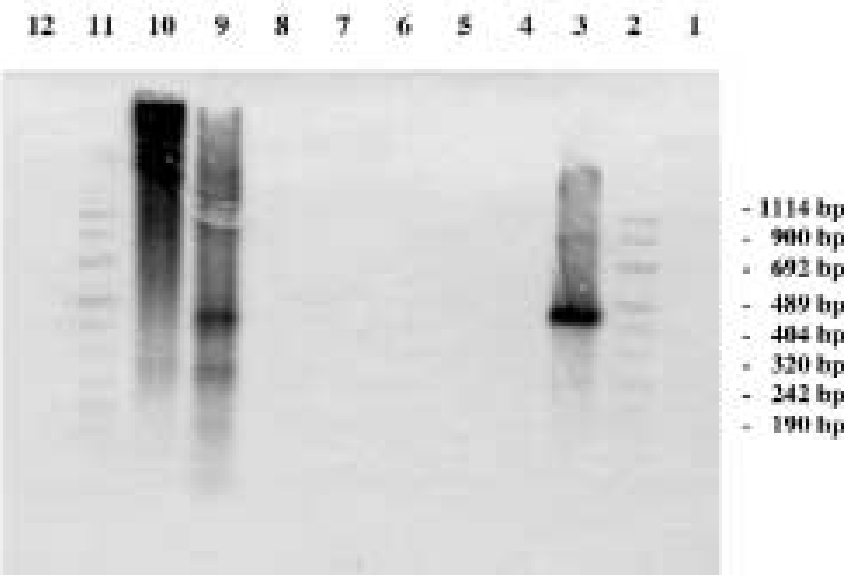

Fig. 2. PCR products obtained after solution-phase RT-nested PCR in the agarose gel electrophoresis (A) and corresponding Southern blot (B), Lanes 1 and 12, 100 bp ladders; lanes 2 and 11, DIG-labeled ladders, lengths are shown on the right side; lane 3, amplicons (447 bp) after 60 PCR cycles with an annealing temperature of $70^{\circ} \mathrm{C}$; lane 4 , omission of extrinsic primers in the first PCR; lane 5, omission of extrinsic primers and Taq DNA polymerase in the first PCR; lane 6, without reverse transcription; lane 7, after pretreatment of templates with RNAse; lane 8, without templates; lane 9, PCR products from lane 10 after treatment with restriction endonuclease $B s i$ HKA I; lane 10 , high molecular weight products after $60 \mathrm{PCR}$ cycles with an annealing temperature of $52^{\circ} \mathrm{C}$.

cleotide sequence specific for $\mathrm{sPLA}_{2}-\mathrm{mRNA}$. Thus, only the mRNA being investigated was translated to cDNA during the reverse transcription. (ii) To obviate amplification of genomic DNA, extrinsic as well as intrinsic primers were designed to span splicing sites between 2 exons. Preliminary investigations on isolated genomic DNA as template proved the efficiency of this approach (not shown). (iii) To prevent the diffusion of amplicons both within and out of the cells, the extrinsic primers were provided with complementary $5^{\prime}$-tails, as first described by Chiu et al. [1]. During amplification these tails lead to the generation of concatamers with a length of more than thousand base pairs. The result is a steric hindrance connected with the anchoring of amplicons at the site of origin, whereby a diffusion of amplified nucleic acid fragments within and out of the cells becomes impossible. To test whether or not the concatamers in fact arose out of the polymerization of monomeric sPLA $\mathrm{A}_{2}$-specific amplicons, the products were incubated with the restriction endonuclease BsiHKA I. The endonuclease cuts the downstream extrinsic primer 32 nucleotides from the $5^{\prime}$-tail, so that products with a length of $429 \mathrm{bp}$ resulted. In the Southern blot along with the 429 bp product a minor band of length 267 bp was recognizable, whose formation can be explained by the annealing of the intrinsic $5^{\prime}$-primer $150 \mathrm{bp}$ upstream from the extrinsic $5^{\prime}$-primer sequence and the following cutting of the $3^{\prime}$-primer sequence at the $5^{\prime}$-end of the concatamers. (iv) To pre- vent the nonspecific incorporation of the DIG-labeled nucleotides as part of "DNA repair mechanisms" and "endogenous priming of DNA-fragments", the cDNA was amplified in two steps in the presence of nested primers. In the first PCR the targets were copied under application of unlabeled nucleotides and extrinsic primers in a maximum of PCR cycles possible without destroying the cell morphology. Thus, along with the amplification of the target, fragmented endogenous DNA were then repaired without becoming accessible to a subsequent immunochemical analysis. The same applied to "endogenous DNA priming". Only in a second PCR consisting in one denaturating and one annealing/elongation reaction, nucleic acids were marked by addition of DIG-labeled nucleotides in the presence of intrinsic primers. In this way artefacts possibly generated during the first PCR step are not recorded by the immunochemical detection.

Furthermore, the solution-phase studies indicated that an annealing of the $5^{\prime}$-tails of the amplicons at an annealing temperature of $70^{\circ} \mathrm{C}$, at which the intrinsic primers anneal, did not occur. This represents a prerequisite for the effective application of the nested primers in the second PCR. Because, in comparison to the solution-phase RT-PCR, in the in situ investigations smaller signal intensities per cell could be assumed, colloidal gold-labeled anti-DIG-antibodies and the silver-enhancement technique was used instead of the alkaline phosphatase conjugates. Along with in- 

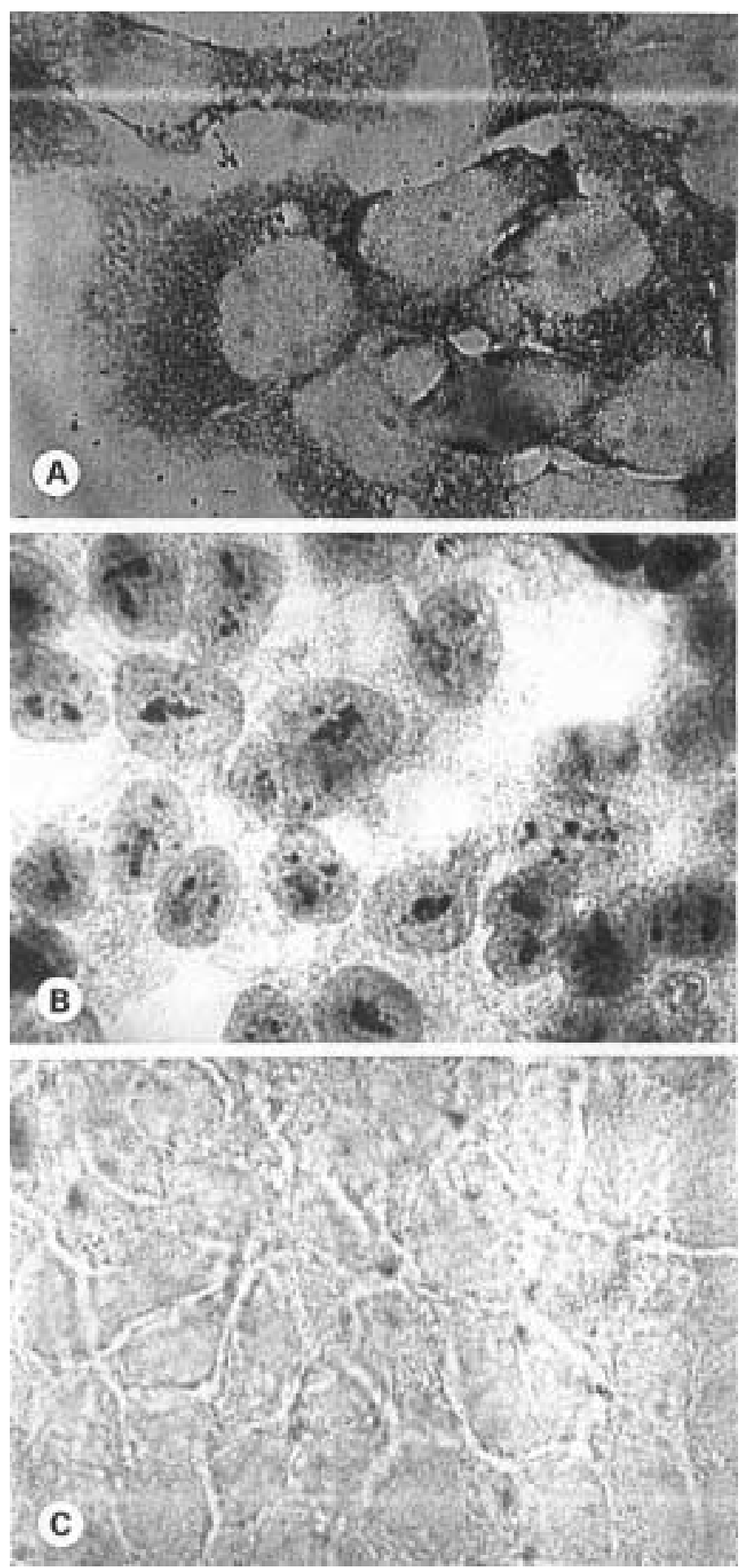

Fig. 3. Identification of $\mathrm{sPLA}_{2}$-mRNA in human $\mathrm{HepG}_{2}$ cells by in situ RT-nested PCR before (A) and after (C) pretreatment of cells with RNAse. In comparison, Mayer's hematoxylin counterstaining was used (B). Original magnification $\times 1000$. 
creased sensitivity this analysis technique has the advantage of being independent of the presence of endogenous enzyme activities and not subject to diffusion.

By applying the optimized in situ RT-nested PCR together with nuclear counterstaining on HepG2 cell cultures, immunostainings were predominantly in the cytoplasms in accordance with mRNA localization. Moreover, the circumstance that the immunostainings were not evenly distributed but rather appeared as granules in the cytoplasms of the cells and individual compartments within the cytoplasm were excluded argues that, with the help of concatamer production, the amplicons are fixed at their place of origin and are not free in the cytoplasm and can not diffuse into other compartments, for example, the nuclei or cellular inclusions.

Numerous studies have demonstrated that after fixation with formalin, nucleic acids in tissue are present in fragments, and that the size of the DNA fragments are strongly dependent on the fixation time. Thus, after a fixation period of one day, in archival formalinfixed and paraffin-embedded tissues, a lower amplification of 345 bp DNA was observed when compared with those of 167 and 262 bp DNA [6]. We obtained similar results in the investigation of $\mathrm{SPLA}_{2}$-specific transcripts in formalin-fixed aortic specimens taken at autopsy. While the amplification of nucleic acid fragments of $161 \mathrm{bp}$ and $260 \mathrm{bp}$ was possible, only in $60 \%$ of the cases under investigation an amplification of $411 \mathrm{bp}$-sized templates from the same gene was observed (unpublished results). These findings are for in situ investigations on archival tissue samples all the more meaningful because it has been found that after in situ PCR, only amplicons with a length of $1200 \mathrm{bp}$ were retained in suspended cells, whereas $600 \mathrm{bp}$-long products were less well retained, and 300 bp products indeed diffused out of the cells [5]. This could also point to a cause for the frequently observed lower amplification effectiveness on sections cut from routinely fixed archival tissues with the in situ (RT)-PCR in comparison with the solution-phase technique [11]. The method of concatamer formation offers an escape route here and shorter DNA and mRNA fragments can be detected whose amplificates otherwise would easily diffuse out of the cells.

To check the specificity of the method presented, along with the positive approaches a series of negative controls was investigated. The result was that in the Southern blot as well as in situ, no immunostainings occurred when the reverse transcriptase step was omitted. The same results were obtained after omission of both extrinsic primers and Taq DNA polymerase as well as after omission of only the primers in the first PCR. From that it follows that the immunostainings are due to specific signals and not to DNA synthesis from "repair-mechanisms" or "mispriming" both in the Southern blot, where in addition, the length of amplicons corresponded to the sequence of $\mathrm{sPLA}_{2}$, as well as in the in situ investigations, where immunostainings were exclusively detectable in the cytoplasm, but not in the nuclei of cells, and where the stainings completely abolished after pretreatment of HepG2 cells with RNAse.

In summary, the results of this study have shown that the described in situ RT-nested PCR technique, which is in comparison to the indirect in situ RT-PCRISH simpler and less time-consuming may circumvent many of previously encountered technical problems with the in situ amplification of nucleic acids. The extent to which this technique with paraffin-embedded archival human aortic specimens leads to a similarly effective amplification and specific detection of intracellular nucleic acids will be the subject of further investigations.

\section{Acknowledgement}

This study was supported by a grant (Ja 565/3-2) from the Deutsche Forschungsgemeinschaft.

\section{References}

[1] K.P. Chiu, S.H. Cohen, D.W. Morris and G.W. Jordan, Intracellular amplification of proviral DNA in tissue sections using the polymerase chain reaction, J. Histochem. Cytochem. 40 (1992), 333-341.

[2] P. Chomczynski and N. Sacchi, Single step method of RNA isolation by acid guanidine isothiocyanate-phenol-chloroform extraction, Anal. Biochem. 162 (1987), 156-159.

[3] R. Crowl, C. Stoner, T. Stoller, Y.C. Pan and R. Conroy, Isolation and characterization of cDNA clones from human placenta coding for phospholipase $\mathrm{A}_{2}$, Adv. Exp. Med. Biol. 279 (1990), 173-184.

[4] R.M. Crowl, T.J. Stoller, R.R. Conroy and C.R. Stoner, Induction of a phospholipase $\mathrm{A}_{2}$ gene expression in human hepatoma cells by mediators of the acute phase response, J. Biol. Chem. 266 (1991), 2647-2651.

[5] A.T. Haase, E.F. Retzel and K.A. Staskus, Amplification and detection of lentiviral DNA inside cells, Proc. Natl. Acad. Sci. USA 87 (1990), 4971-4975. 
[6] T. Inoue, K. Nabeshima, H. Kataoka and M. Koono, Feasibility of archival non-buffered formalin-fixed and paraffin-embedded tissues for PCR amplification: an analysis of resected gastric carcinoma, Pathol. Int. 46 (1996), 997-1004.

[7] K. Ivarsson and B. Weijdegard, Evaluation of the effects of DNase treatment on signal specificity in RT-PCR and in situ RT-PCR, Biotechniques 25 (1998), 630-632.

[8] J. Koch, J. Hindkjaer, J. Mogensen, S. Kovraa and L. Bolund, An improved method for chromosome-specific labeling of alpha satellite DNA in situ by using denatured double-stranded DNA probes as primers in a primed in situ labeling (PRINS) procedure, Genet. Anal. Tech. Appl. 8 (1991), 171-178.

[9] P. Komminoth, V. Adams, A.A. Long, J. Roth, P. Saremaslani, R. Flury, M. Schmid and P.U. Heitz, Evaluation of methods for hepatitis $\mathrm{C}$ virus detection in archival liver biopsies: comparison of histology, immunohistochemistry, in-situ hybridization, reverse transcriptase polymerase chain reaction (RT-PCR) and in-situ RT-PCR, Pathol. Res. Pract. 190 (1994), 1017-1020.

[10] P. Komminoth and M. Werner, Target and signal amplification: approaches to increase the sensitivity of in situ hybridisation, Histochem. Cell. Biol. 108 (1997), 325-333.

[11] A.A. Long, P. Komminoth, E. Lee and H.J. Wolfe, Comparison of indirect and direct in-situ polymerase chain reaction in cell preparations and tissue sections, Histochemistry 99 (1993), 151-162.

[12] T. Maniatis, E.F. Fritsch and J. Sambrook, Molecular Cloning: A Laboratory Manual, Cold Spring Harbor Laboratory, NY, 1982.

[13] M. Menschikowski, M. Kasper, P. Lattke, A. Schiering, S. Schiefer, H. Stockinger and W. Jaross, Secretory group-II phos- pholipase $\mathrm{A}_{2}$ in human atherosclerotic plaques, Atherosclerosis 118 (1995), 173-181.

[14] M. Menschikowski, M. Vogel, G. Dinnebier and W. Jaross, Detection of phospholipase $\mathrm{A}_{2}$-specific mRNA in cytokinestimulated HepG2 cells by in situ-RT-nested PCR, Anal. Cell. Pathol. 13 (1997), S91.

[15] M. Menschikowski, A. Rosner-Schiering, R. Eckey, E. Mueller, R. Koch and W. Jaross, Expression of secretory group IIA phospholipase $\mathrm{A}_{2}$ in relation to the presence of microbial agents, macrophage infiltrates, and transcripts of proinflammatory cytokines in human aortic tissues, Arterioscler. Thromb. Vasc. Biol. 20 (2000), 751-762.

[16] M. Morita, H. Hachisuka and Y. Sasai, Detection of genomic DNA with a high sensitivity in tissue sections using a two step cycling in situ PCR procedure, Kurume Med. J. 41 (1994), 215-220.

[17] G.J. Nuovo, F. Gallery, R. Hom, P. MacConnell and W. Bloch, Importance of different variables for optimizing in situ detection of PCT-amplified DNA, PCR Methods Applic. 2 (1993), 305-312.

[18] J. Peters, J. Krams, H.H. Wacker, A. Carstens, D. Weisner, K. Hamann, M. Menke, D. Harms and R. Parwaresch, Detection of rare RNA sequences by single-enzyme in situ reverse transcription-polymerase chain reaction. High-resolution analyses of interleukin-6 mRNA in paraffin sections of lymph nodes, Am. J. Pathol. 150 (1997), 469-476.

[19] J.F. Sällström, M. Alemi, H. Spets and I. Zehbe, Nonspecific amplification in in-situ PCR by direct incorporation of reporter molecules, Cell Vision 1 (1994), 243-251. 


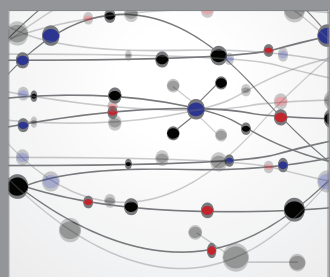

The Scientific World Journal
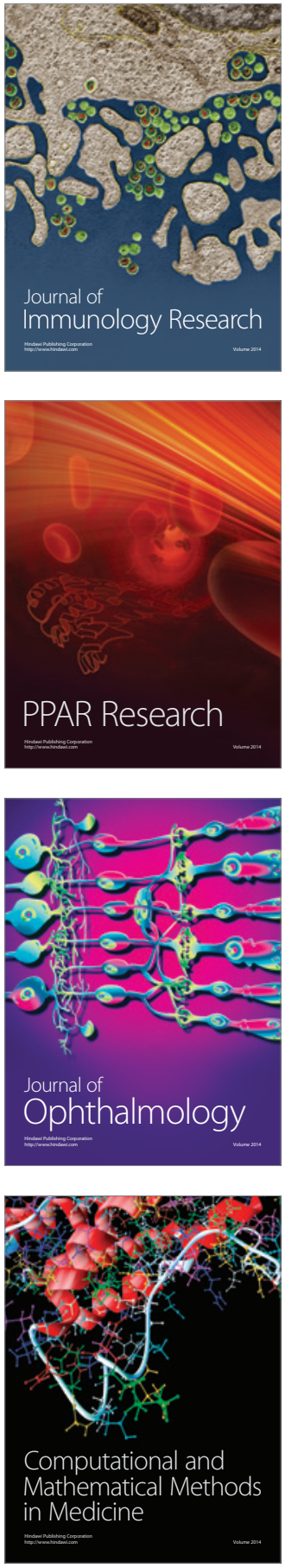

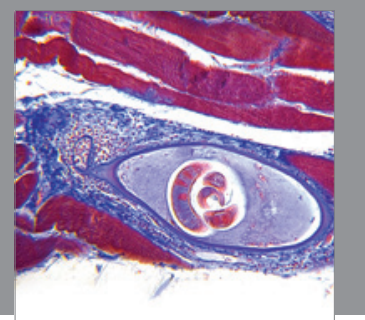

Gastroenterology

Research and Practice
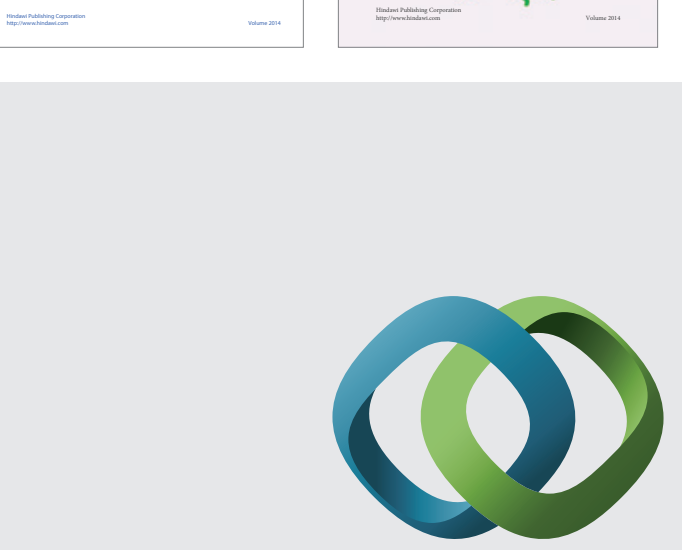

\section{Hindawi}

Submit your manuscripts at

http://www.hindawi.com
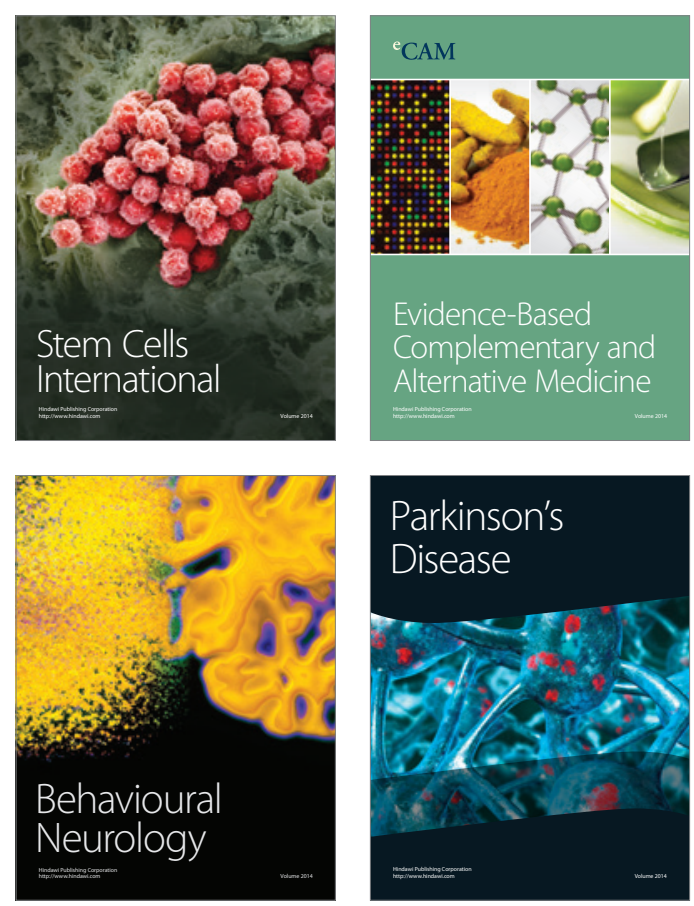

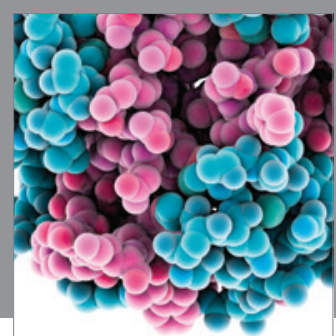

Journal of
Diabetes Research

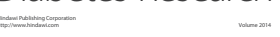

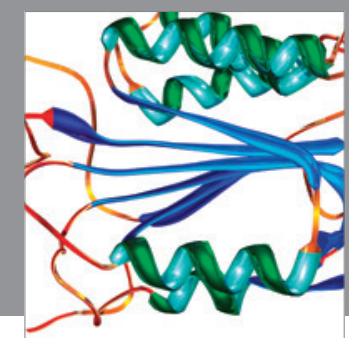

Disease Markers
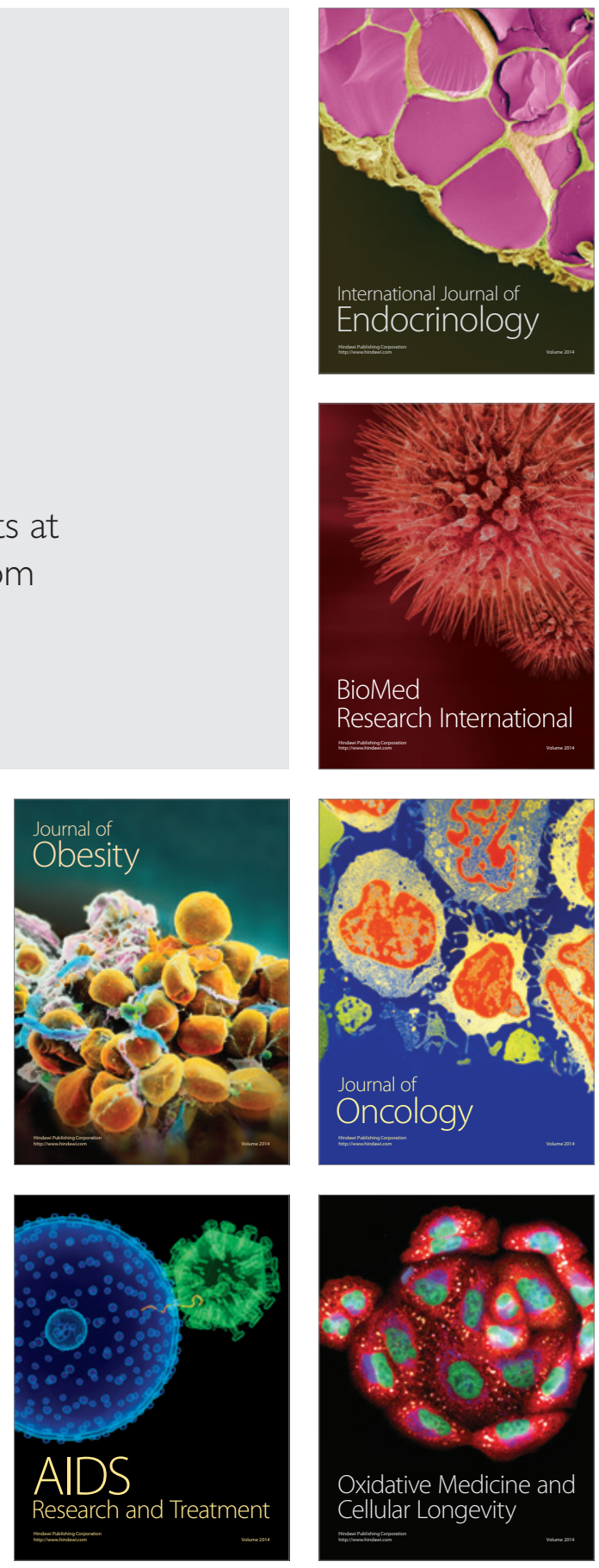